\title{
12. Developing an institutional legal framework for sustainable regional water management in times of climate change
}

\author{
Marleen van Rijswick and \\ Imelda U. Tappeiner
}

\section{INTRODUCTION}

The availability of enough clean water for man and nature and protection against flooding are two of the toughest challenges with which society has to deal. Climate change makes this even more urgent. Ensuring human dignity and equity and the protection of ecosystems and natural resources strongly depends on appropriate water management. Besides researching several principles and concepts that have been developed to deal with water management and climate change, this contribution tries to develop an analytical legal framework for the institutional design of regional and local water management. Lessons can be learnt from other disciplines, like social and political sciences, economics, environmental sciences and public administration. Because disasters provide an opportunity to learn, adapt and improve a legal and governance system we can say that more disasters bring about more learning. A thousand years of local and regional water management in the Netherlands in which many lessons have been learned therefore seems to be an appropriate case study.

\section{WATER MANAGEMENT AND CLIMATE CHANGE: LEADING REQUIREMENTS}

Good water management should fulfil three overarching requirements. It should be legitimate, effective and resilient. 
Adaptation to climate change requires - among other things - adaptive water management. The most important tasks in the field of water management when it comes to adaptation to climate change are flood risk management, fresh water supply and water ecology. In this chapter we will use the Intergovernmental Panel on Climate Change (IPCC) definition of adaptation: "the adjustment in natural or human systems in response to actual or expected climatic stimuli or their effects, which moderates harm or exploits beneficial opportunities'. ${ }^{1}$ Adaptation is closely related to resilience and has also been described as reducing the sensitivity of the system to climate change; altering the exposure of the system to climate change; and increasing the resilience of the system to cope with changes. ${ }^{2}$ Sensitivity and exposure are often linked to "vulnerability'. ${ }^{3}$ Adaptation strategies in general are defined as 'a general plan of action for addressing the impacts of climate change, including climate variability and extremes'. ${ }^{4}$ It will include a mix of policies and measures with the overarching objective of reducing the country's vulnerability.

A legitimate adaptation policy must be able to ensure transparency, accountability, fairness and equity. Legitimacy can be described in rather narrow legal terms, focusing on what is called 'input legitimacy'. Is the way in which water management is determined in accordance with the rule of law, being based on legality, separation of powers and democracy? How, and by whom, are the public interests that are at stake defined; and are regulations, plans and decisions taken in accordance with democratic requirements and stakeholder participation? Legal aspects of legitimacy, however, do not only include the question whether the government or the state has the power to regulate climate adaptation, but also the way in which it executes these powers. ${ }^{5}$ Therefore throughput and output legitimacy are also important, which focuses on the effectiveness of the way policy goals are achieved or not achieved and on the question

\footnotetext{
1 IPCC, Climate Change. The Fourth Assessment Report, Contribution of Working Group II, WMO 6 (IPCC, 2007), Appendix I, Glossary A-D.

2 W.N. Adger, N.W. Arnell and E.L. Tompkins, 'Successful Adaptation to Climate Change across Scales', (2005) 15 Global Environmental Change 77.

3 W.N. Adger, 'Vulnerability', (2006) 16 Global Environmental Change 268.

4 G.R. Biesbroek et al., 'Europe Adapts to Climate Change: Comparing National Adaptation Strategies', (2010) 20 Global Environmental Change 441.

5 A. van Buuren, P. Driessen, G. Teisman and H. van Rijswick, 'Towards Legitimate Governance Strategies for Climate Adaptation in the Netherlands: Combining Insights from a Legal, Planning, and Network Perspective', (2013) Regional Environmental Change 2, DOI 10.1007/s10113-013-0448-0.
} 
whether the public are satisfied with the outcome of the climate adaptation policies. Does it offer what they expected?

An effective water adaptation policy must be able to address the adaptation task decisively and efficiently through the right mix of norms, instruments, competent authorities and stakeholders, strategies and processes.

Resilience, a concept originating within the domain of natural science to address changes in equilibriums in ecological systems, has entered the field of social sciences related to the study of social-ecological systems. ${ }^{6}$ Resilience is often used to mean the amount of change or disturbance that a social-ecological system can absorb and persist with before it is reorganized into a new equilibrium. ${ }^{7}$ A policy directed towards climate adaptation can be described as aiming to decrease the vulnerability of a system to climate change and to increase the system's resilience in coping with such climate change. ${ }^{8}$ It should therefore be capable of both enabling autonomous adaptation and building long-term capacity. In a legal context, vulnerability and resilience may have a specific meaning. 'Vulnerability' could refer to a duty of care for the government and societal parties; for instance the protection of the living environment and public health and, concerning the topic of this chapter, water management. 'Resilience' might relate to the strength and flexibility of a legal system to cope with problems of climate change as, for example, uncertain risks. ${ }^{9}$ This can be achieved by a greater legal role for principles - think of the precautionary principle for instance - a different type of norm and standard setting, adaptive planning, monitoring, ${ }^{10}$ duties to revise permits in case of changed circumstances and legal instruments that allow governments to take measures that increase the resilience of society against the risks of climate change. However, the law is meant to offer a stable basis for organization, as well as legal

6 C. Folke, 'Resilience: The Emergence of a Perspective for SocialEcological Systems Analyses', (2006) 16 Global Environmental Change 253.

7 C.S. Holling, 'Resilience and Stability of Ecological Systems', (1973) 4 Annual Review of Ecology and Systematics 1.

8 P.P.J. Driessen and H.F.M.W. van Rijswick, 'Normative Aspects of Climate Adaptation Policies', (2011) Climate Law 1-23.

9 L. Francot-Timmermans and U. de Vries, 'Eyes Wide Shut: On Risk, Rule of Law and Precaution', (June 2013) 26:2 Ratio Juris, International Journal of Jurisprudence and Philosophy of Law 282-301.

10 B.A. Beijen, H.F.M.W. van Rijswick and H. Tegner Anker, 'The Importance of Monitoring for the Effectiveness of Environmental Directives: A Comparison of Monitoring Obligations in European Environmental Directives', (2014) 10(2) Utrecht Law Review 126-135. 
certainty and protection against unlawful or arbitrary behaviour. Legal resilience and flexibility is therefore limited inter alia by the rule of law and the need for legal certainty. ${ }^{11}$ Therefore a match should be found between an adaptive, robust or resilient legal system, on the one hand, and safeguarding legal certainty and the rule of law, on the other. ${ }^{12}$ The way the match between adaptiveness and the rule of law will be designed strongly depends on the values and normative goals in a society, its political system and the way responsibilities are shared between public and private parties. ${ }^{13}$ This brings us to the need for clarity as to the main normative goals in society, but also to the need for clarity concerning the public interest, the way it is defined and how it is elaborated in practice. ${ }^{14}$

The three elements of legitimacy, effectiveness and resilience are closely interwoven. Using a broad concept of legitimacy, we argue that an adaptation policy that is not effective will in the end suffer from a lack of output legitimacy. A policy that is not resilient and is not able to adapt to changing circumstances will lose its legitimacy too. A legal system which is too resilient, however, will lack legitimacy when it is not in conformity with the rule of law and the need for legal certainty, since these two elements are basic needs for a stable society and a confidencebuilding government, on which people need to be able to rely. The same can be argued for an effective policy that is not in conformity with legitimacy requirements.

11 O. Green, A. Garmestani, H. van Rijswick and A. Keessen, 'EU Water Governance: Striking the Right Balance between Regulatory Flexibility and Enforcement?' (2011) 18(2) Ecology and Society 10; A.M. Keessen and H.F.M.W. van Rijswick, 'Adaptation to Climate Change in European Water Law and Policy', (November 2012) Utrecht Law Review 38-50, available at www.utrechtlawreview.org; J. Ebbesson, 'The Rule of Law in the Governance of Complex Socio-ecological Changes', (2010) 20 Global Environmental Change 415-417.

12 M. van Rijswick and W. Salet, 'Enabling the Contextualization of Legal Rules in Responsive Strategies to Climate Change', (2012) 17(2) Ecology and Society 18.

13 A.M. Keessen, J. Hamer, H.F.M.W. van Rijswick and M. Wiering, 'The Concept of Resilience from a Normative Perspective: Examples from Dutch Adaptation Strategies', (2013) 18(2) Ecology and Society 45.

14 J. Tennekes, P.P.J. Driessen, H.F.M.W. van Rijswick and L. van Bree, 'Out of the Comfort Zone: Institutional Context and the Scope for Legitimate Climate Adaptation Policy', (2013) Journal of Environmental Policy \& Planning, DOI:10.1080/1523908X.2013.836961. 


\section{GOOD WATER MANAGEMENT: THE FOUR MAIN ELEMENTS}

Our statement is that ensuring good water management requires an integrated approach of institutional, legal, economic and technical arrangements. These four elements will be briefly described.

Institutional elements within the legal framework concern the division of responsibilities over several governmental layers and between public and private parties. The institutional arrangement is preferably related to the concept of river basin management, in which hydrological borders are used as an organizing principle. Furthermore, theories of integrated water resource management (IWRM) and common pool resource management (CPRM) may provide useful elements for the institutional legal design. Furthermore, also the role of all interested parties in decision-making processes is an institutional element. This role can best be achieved by a mix of constitutional representation and mechanisms to ensure the availability of information and public participation. A pertinent discussion concerns the right to water and the way this right can be implemented in the various legal systems. The right to water is not formally part of European ${ }^{15}$ or Dutch ${ }^{16}$ constitutional water law. One can find this right in directives and national laws that combine the right to water with natural resource management and traditional human rights. ${ }^{17}$ We mention the importance of both substantive and procedural elements of the right to water as they are also of importance for the institutional legal framework. Substantive elements that can be derived from international law are the protection of the quality of water: safe and free from micro-organisms and chemical substances; the accessibility of water and water services; and a sustainable and equitable use of scarce fresh water. European and Dutch law add to this protection against flooding, the protection of ecosystems and a fair price for water services. Procedural elements are the accessibility of relevant information, transparency, participation in decision making, accountability and access to justice.

15 H. van Rijswick, 'Searching for the Right to Water in the Legislation and Case Law of the European Union', in H. Smets (ed.), The Right to Safe Drinking Water and Sanitation in Europel Le droit à l' eau potable et à assainissement, sa mise en oeuvre en Europe (Académie de l'eau, Editions Johanet, 2012), 87-113.

16 H. van Rijswick, 'Improving the Right to Water in the Netherlands', in Smets (above, note 15), 369-391.

17 H.J.M. Havekes and H. van Rijswick, European and Dutch Water Law (Europa Law Publishing, 2012), Chapter 2. 
Legal instruments are necessary to provide the required instruments for governments and the public to realize good water management. Depending on the legal culture and tradition of a state, the status of water may differ. Looking at, for example, the European Union we can see that water is not regarded as a commercial product like any other but as heritage which must be treated and defended as such (preamble to the Water Framework Directive). In the Netherlands water is a public good. It belongs to everyone and nobody, and is regarded as a common pool. The main question is how to avoid a tragedy of this commons. Depending on the status of water, legal instruments can be based on a water rights-based approach or on the regulation of water as a public good. European water law shows several elements that improve the legitimacy, effectiveness and resilience of water management, like the formulation of the public interest that a government wants to protect by setting clear goals and standards, with a revision after regular periods and adequate exemptions, the investigation of the current situation of a river basin, the impact of human activities, the main threats and the use of a planning cycle process. ${ }^{18}$ Because European Union law leaves it to the Member States how directives are implemented in their national laws and also gives Member States the necessary freedom as to how they constitutionally organize water management, there are great differences between Member States in the institutional and organizational aspects of water management. ${ }^{19}$ In the Netherlands, for example, we can see that both strategic and operational planning are divided between the central, the provincial, the regional and the local levels.

Furthermore, a strong role for monitoring and the use of a mix of regulation tools improves the legitimacy, effectiveness and resilience of water management. Depending on the different situations in various states it is advisable for the legislator and the executive bodies to choose the most appropriate legal instruments. It should be noted, however, that the right mix of instruments should ensure mechanisms for the fair distribution of risks, costs, benefits and use of water. When we look at

18 O. Green, A. Garmestani, H. van Rijswick and A. Keessen, 'EU Water Governance: Striking the Right Balance between Regulatory Flexibility and Enforcement?' Ecology and Society 18(2): 10. http://dx.doi.org/10.5751/ES05357-180210; A.M. Keessen and H.F.M.W. van Rijswick, 'Adaptation to Climate Change in European Water Law and Policy', (November 2012) Utrecht Law Review 38-50.

19 A. Keessen, J. van Kempen, H. van Rijswick, J. Robbe and Ch. Backes, 'European River Basin Districts: Are They Swimming in the Same Implementation Pool?', (2010) 22 Journal of Environmental Law 197-222. 
existing distribution mechanisms we can see that in the Netherlands these mechanisms operate on a 'first come, first served' basis, which leads to the question whether this system is sufficiently fair. In international water law we see the concept of 'reasonable use', but experience shows that this is difficult to realize. Furthermore, we can distinguish mechanisms such as quota or ranking, planning and regulation, land-use planning and economic instruments (see below). There are several possibilities and one should choose those that are most appropriate for the national, historical, cultural and legal tradition of a state. Because no distribution system is perfect, we would suggest a combination of distribution mechanisms.

Economic instruments are also crucial for the realization of sustainable water management. The main principles thereof, such as the user pays and the polluter pays, or more recently developed instruments such as payments for ecosystem services, are well known. In the European Water Framework Directive a new obligation has been introduced in Article 9: the cost recovery for water services, which has a broader scope than the traditional 'polluter pays' principle. ${ }^{20}$ How arrangements that ensure cost recovery are legally elaborated may differ from state to state, depending on the legal tradition. We can see, for example, the use of taxes and levies, water pricing, tradable water-use rights and insurance systems.

Finally, technical measures are the cornerstone of water management. Building dikes, irrigation systems, drinking-water supply systems, sewerage and waste water treatment installations is of course a crucial element of water management. It should however be stressed that technical measures alone, without an accompanying governance system, will in the end not be able to provide for legitimate and sustainable water management. ${ }^{21}$

20 See also P.E. Lindhout, 'A Wider Notion of the Scope of Water Services in EU Water Law: Boosting Payment for Water-Related Ecosystem Services to Ensure Sustainable Water Management?', (2012) 8(3) Utrecht Law Review 86; P.E. Lindhout, 'Application of the Cost Recovery Principle for Water Services in the Netherlands', (2013) 10(4) Journal for European Environmental and Planning Law 309-332.

21 OECD, Water Governance in OECD Countries: A Multi-level Approach (2011) available at www.oecd.org (last accessed 22 July 2014). 


\section{GOOD WATER GOVERNANCE: TEN LEADING LEGAL AND POLICY PRINCIPLES}

\section{Ten Leading Principles}

Water management and the way society adapts to climate change are always value-laden. ${ }^{22}$ Normative judgements can be based on world views and principles as to what should, and what should not, be done in society, and on the societal and economic interests that are at stake. ${ }^{23}$ Some of these normative opinions are embedded in legislation and regulations (on the international, the supranational and the national level); for instance, in the form of guiding principles and standards. ${ }^{24}$ Other normative positions are not similarly embedded and, as a result, can vary considerably in time and place. In most modern societies there are certain principles - often, but not always, embedded in laws and international treaties - which are taken as points of departure for intervening or not intervening in societal processes. ${ }^{25}$ Those points of departure must lead to interventions that are legitimate, both in the sense of being 'legally based' and 'acceptable and transparent'. Looking at the literature on water management and climate change we can derive ten leading principles, which can or even should guide the actions of governments and private parties. International law is agenda setting and it prepares national states and citizens for new developments within general frameworks. ${ }^{26}$ Concepts such as 'sustainability', 'good neighbourliness' and the 'precautionary principle' result from international law. Regarding

22 R. Cook, Legal Responses for Adaptation to Climate Change. The Role of the Principle of Equity and Common but Differentiated Responsibility (Utrecht University, 2010), available at: www.milieurecht.nl (last accessed 22 July 2014); R. Cook and E. Tauschinsky, 'Accommodating Human Values in the Climate Regime', (2008) 4 Utrecht Law Review 18-34.

23 M. van Rijswick and W. Salet, 'Enabling the Contextualization of Legal Rules in Responsive Strategies to Climate Change', (2012) 17:2 Ecology and Society 18, available at http://dx.doi.org/10.5751/ES-04895-170218.

24 P.P.J. Driessen and H.F.M.W. van Rijswick, 'Normative Aspects of Climate Adaptation Policies', (2011) Climate Law 1-23.

25 N. De Sadeleer, Environmental Principles: From Political Slogans to Legal Rules (Oxford University Press, 2005); J.H. Jans and H.D. Vedder, European Environmental Law After Lisbon (Europa Law Publishing, 2012), 35-46; R. Marcrory (ed.), Principles of European Environmental Law (Europa Law Publishing, 2004).

26 Ch. Sabel and J. Zeitlin, Experimentalist Governance in the European Union: Towards a New Architecture (Oxford University Press, 2010). 
climate change, it should be noted that the most important principles follow from the international legal framework on climate change, namely the United Nations Framework Convention on Climate Change (UNFCCC). Besides the principles that follow directly from Water treaties, Environmental Treaties and the UNFCCC and its implementation in domestic law, most states rely on legal and policy principles that are of a more general nature within their legal system, but which are also relevant for national and regional water management and climateadaptation policies. However, the role that normative principles play in practice will strongly depend on one's view of the public and private interests at stake. We distinguish five main principles in the UNFCCC:27 equity, ${ }^{28}$ solidarity, ${ }^{29}$ precaution, ${ }^{30}$ sustainability ${ }^{31}$ and good neighbourliness. ${ }^{32}$ The UNFCCC also recalls in its preamble that states, in accordance with the UN Charter and the principles of international law, have the sovereign right to exploit their own resources under their own environmental and developmental policies, and a responsibility to ensure that activities within their jurisdiction or control do not cause damage to the environment of other states or to areas beyond the limits of national jurisdiction. The backbone of the UNFCCC is the principle of equity, as laid down in Article 3. Equity concerns present as well as future generations. Equity deals with substantive and procedural fairness. Distributive fairness is based on the principle of solidarity, and may require a rebalancing of inequalities in wealth, risks and financial or other excessive burdens.

We see the following principles as guiding principles for water management and adaptation to climate change: equity (procedural and substantive fairness); solidarity (distributive fairness); good neighbourliness; protection of property rights; sustainability and the non-shift principle; the proportionality principle; the user and polluter pays principle and cost recovery for water services; the precautionary principle; the subsidiarity principle; and the concept of decentralization. In this chapter we focus on institutional elements and will further elaborate on the concept of decentralization.

27 T.M. Thorp, 'Climate Justice: A Constitutional Approach to Unify the Lex Specialis Principles of International Climate Law', (November 2012) 8(3) Utrecht Law Review.

28 Article 3 (1) of the UNFCCC.

29 Article 3 (2) of the UNFCCC.

30 Article 3 (3) of the UNFCCC.

31 Article 3 (4) of the UNFCCC.

32 Article 3 (5) of the UNFCCC. 


\section{The Concept of Decentralization}

The concept of decentralization is based on international and national constitutional law and is regarded as an important element for a wellfunctioning state in which local communities are involved in policy and decision making. Research into IWRM and CPRM also stresses the importance of multi-level government. Huntjes refers to this as the need for more polycentric systems to improve adaptive governance, based on the work of, among others, Ostrom. ${ }^{33}$ In this chapter we focus on institutional elements, with a special emphasis on decentralization.

From a constitutional law perspective centralization can roughly be defined as the exercise of power from a central point in a given administrative unit. Decentralization, on the contrary, means the exercise of power 'away from the centre'. ${ }^{34}$ The core is that the exercise of decentralized authorities' powers is not subordinate to the central state power. Decentralized authorities have a certain degree of autonomy from the central government. This element is important because it enables us to distinguish decentralization from other forms of governance in which the law attributes powers to an authority and these powers are exercised in the name of this authority and under its responsibility, but the authority itself is subordinate to a higher authority. However, decentralization in the sense of not being subordinate to the central government does not mean that there is no relationship at all between the central and the decentralized governments. This relationship does exist, but its shape and intensity can vary and depend on the state form - a confederation, federation or a unitary state - in which that relationship exists. In constitutional law it is assumed that decentralization specifically means that the power to impose binding regulations and administrative acts on citizens must also be given to authorities other than the central authority. Persons belonging to a 'community' exert control through democratic instruments over how attributed powers are exercised. The community

33 P. Huntjes, Water Management and Water Governance in a Changing Climate: Experiences and Insights on Climate Change Adaptation in Europe, Africa, Asia and Australia (Eburon, 2011), 43-44.

34 A.W. Heringa and P. Kiiver, Constitutions Compared: An Introduction to Comparative Constitutional Law (Intersentia, 2012); L. Prakke and C.A.J.M. Kortmann (eds.), Constitutional Law of 15 EU Member States (Kluwer, 2004); M. Rosenfeld and A. Sajó, The Oxford Handbook of Comparative Constitutional Law (Oxford University Press, 2012); D.J. Elzinga and R. de Lange, Handboek van het Nederlandse Staatsrecht (Kluwer, 2006); H.P.J.A.M. Hennekens, H.J.A.M. Van Geest and R. Fernhout, Decentralisatie (Ars Aequi Libri, 1998). 
has frequently been given legal personality and regulatory power. ${ }^{35}$ Municipalities are a well-known and concrete example of such decentralized authorities. In the Netherlands, regional water authorities (water boards) are another good example of local authorities with a very long and glorious history. Typical of water boards, however, is that they only exercise powers in relation to their specific task - water management - in a particular area within the territory of the state, based on a (sub-)river basin. In that way they differ from municipalities whose tasks are not restricted to a specific goal.

\section{Decentralization and Legitimacy}

The basic principles of a state based on the rule of law are the principles of legality, fundamental rights, separation of powers and judicial review. Decentralization is a corollary of two main principles of a democratic state which is subject to the rule of law: separation of powers and democracy. Since a concentration of power can lead to abuse and arbitrariness the rationale behind the principle of the separation and spreading of powers is that this minimizes those risks. In many systems of constitutional law in unitary states as well as federal states, the decentralization of legislation and administration to local authorities in regions, provinces or municipalities is one of the modalities for spreading the exercise of power. ${ }^{36} \mathrm{~A}$ democratic state is also founded on the principle of democracy, the concept that communities should rule themselves. The concept of democracy is a complex one, but the 'basic package' of a democratic state includes the right to vote and to be elected and the right to exercise fundamental political rights. It further includes the requirement that an elected representative can effectively influence the decision making ex ante and can effectively control the executive power ex post. It includes decision making by majority rule and that the rights of minorities are respected. Of great importance, finally, is the requirement of the openness of decision making and the transparency of government. In short, the principle of democracy requires that citizens effectively influence law making and control the administration so that the elected representative bodies can legitimize the government's actions. Of great importance here is that decentralized authorities can exercise their law-making and administrative powers with a high degree of autonomy from the central government. Within the concept of decentralization a

35 Prakke and Kortmann (above, note 34).

36 See for some European countries: Prakke and Kortmann (above, note 34). 
distinction can be made between territorial decentralization and functional decentralization. The former means that the Constitution or an Act of Parliament attributes general legislative and administrative powers concerning matters of local interest to autonomous authorities having legal personality in a territorially circumscribed jurisdiction. The bodies of the authorities are elected by the citizens living in that territory. A good example of territorial decentralization is the provinces and the municipalities. Functional decentralization means that the Constitution or an Act of Parliament attributes decision-making powers in respect of specific tasks. In the Netherlands the water boards (waterschappen) are a good example of functional decentralization on a particular territory. ${ }^{37}$ The basic elements of the decentralized water boards are the democratic legitimacy of their governing body and financial independence because of their right to raise local taxes, all of which aim at the execution of tasks in the field of water control.

A certain degree of autonomy is also one of the guiding principles of the European Charter of Local Self-Government (The Charter): ${ }^{38}$

The preamble provides an opportunity for a statement of the basic premises underlying the Charter. These are, essentially: the vital contribution of local self-government to democracy, effective administration and the decentralisation of power; the important role of local authorities in the construction of Europe; the need for local authorities to be democratically constituted and enjoy wide-ranging autonomy.

And further:

The Charter commits the parties to applying basic rules guaranteeing the political, administrative and financial independence of local authorities ... Indeed, it embodies the conviction that the degree of self-government enjoyed by local authorities may be regarded as a touchstone of genuine democracy. ${ }^{39}$

37 Article 133 of the Dutch Constitution and Article 1 of the Water Board Act that define their task: water governance on a specific territory.

38 European Charter of Local Self-Government, Strasbourg, 15.X.1985, CETS No. 122. This Charter of the Council of Europe is an international binding treaty that guarantees the rights of communities and their elected authorities. Of the Council of Europe's 47 Member States, 46 have signed and ratified the Charter. On the Charter see: C.M.G. Himsworth, Treaty-Making for Standards of Local Government: The European Charter of Local Self-Government and its Possible Application Beyond Europe (University of Edinburgh School of Law, 2011), Working Paper No. 2011/24.

39 European Charter of Local Self-Government, Strasbourg, 15.X.1985, CETS No. 122, Explanatory Report. 
In order to guarantee an effective implementation, the Charter requires the Member States to embed the principle of local self-government in their domestic law or in their Constitution. States are bound to respect, with no reservation, a core of basic principles such as the right of citizens to participate in managing public affairs; the key rights of communities to enjoy autonomy and self-government, to elect their local bodies and to have their own competences, administrative structures and financial resources; or the right to judicial recourse in case of interference from other levels. In 2009 the Charter was supplemented with provisions in an Additional Protocol guaranteeing the right to participate in the affairs of a local authority. ${ }^{40}$

Decentralization within states is not only based on constitutional principles but is also a result of practical considerations, namely that the exercise of powers is more efficient and effective if it is spread out rather than being exercised from one central government. This is surely the case in states with a large territorial size and a complex social system. The principles of separation of powers and democracy, on the one hand, and pragmatism, on the other, meet each other in the notion that the best exercise of power is that which is closest to the citizen. This, too, is one of the principles expressed in the preamble to the Charter:

- Considering that the local authorities are one of the main foundations of any democratic regime;

- Considering that the right of citizens to participate in the conduct of public affairs is one of the democratic principles that are shared by all member States of the Council of Europe;

- Considering that it is at local level that this right can be most directly exercised;

- Convinced that the existence of local authorities with real responsibilities can provide an administration which is both effective and close to the citizen ...

The basis of decentralization is the principle of democracy and the belief that local authorities are key pillars of a democratic polity. The regulation and management of public affairs must take place where the government is closest to the citizens and where they have a direct influence. ${ }^{41}$ The assumption is that decentralized local authorities are better suited to have

40 Additional Protocol to the European Charter of Local Self-Government on the right to participate in the affairs of a local authority, Utrecht, 16.XI.2009, CETS No.: 207.

41 Article $3 \S 1$ of the European Charter of Local Self-Government. 
those powers when the interest of the local population is at stake; in short, better decisions are made when local communities are actively involved in the decision-making process. This is of course particularly true for specific local needs and concerns, but also for policy fields of a more general nature, such as climate change, energy or public security, where the interest of the citizen may also have a specific local dimension. The general principle is that the exercise of public responsibilities should be decentralized unless compelling reasons indicate otherwise. For example, the Dutch Water Boards Act lays down the principle of decentralization in Article 2 paragraph 2: the task of water management will be assigned to the Water Boards, unless this is not compatible with the interest of the good organization of water management (for the whole country).

\section{The Subsidiarity Principle}

Closely connected to the principle of decentralization is the so-called principle of subsidiarity, the principle that involves the sharing of powers between central and decentralized authorities. This principle implies that local authorities should be responsible for those areas which they are capable of managing more effectively themselves. The European Charter of Local Self-Government is the first treaty to establish the principle of subsidiarity. The application of this principle allows the decentralization of power towards the level which is closest to the citizen. The principle of subsidiarity is laid down in Article $4 \S 3$ of the Charter:

Article 4

3. Public responsibilities shall generally be exercised, in preference, by those authorities which are closest to the citizen. Allocation of responsibility to another authority should weigh up the extent and nature of the task and requirements of efficiency and economy.

This does not imply, however, a requirement of systematically decentralizing functions to such local authorities which, because of their nature and size, can only accomplish limited tasks. ${ }^{42}$ Reasons to refrain from decentralization may lie in the fact that certain powers may be exercised more effectively by the central government, such as protecting national security. Another reason may be that some tasks and powers lie within

42 European Charter of Local Self-Government, Explanatory Report. 
the exclusive competence of the central government and should not be decentralized in a unitary state, for example the defence of the country or conducting foreign policy.

The Charter is a binding treaty under international law; however, there is no specific enforcing mechanism such as a special court where the Charter's rights may be vindicated. The 'Charter does not provide for an institutionalized system of control of its application, beyond a requirement for parties to supply all relevant information concerning legislative or other measures taken for the purpose of complying with the Charter' ${ }^{43}$ It is the Congress of Local and Regional Authorities of the Council of Europe that ensures that the principles enshrined in the Charter are observed. Within the Congress it is in particular the Monitoring Committee that is responsible for monitoring the application of the Charter. Although Article 11 of the Charter provides that 'Local authorities shall have the right of recourse to a judicial remedy in order to secure free exercise of their powers and respect for such principles of local selfgovernment as are enshrined in the constitution or domestic legislation', this does not mean that the provisions of the Charter are directly enforceable in the domestic courts of the Member States. ${ }^{44}$

The law of the European Union also encompasses the principle of subsidiarity, but, it should be stressed, mainly in the relationship between the European Union and the Member States, although, since the Lisbon Treaty, the local and regional authorities have been included. The definition of the subsidiarity principle now explicitly contains the local and regional dimensions and thus underlines the necessity to respect the competences of local and regional authorities within the European Union. Article $5 \S 3$ of the Treaty of the European Union (TEU) reads as follows:

3. Under the principle of subsidiarity, in areas which do not fall within its exclusive competence, the Union shall act only if and in so far as the objectives of the proposed action cannot be sufficiently achieved by the Member States, either at central level or at regional and local level, but can rather, by reason of the scale or effects of the proposed action, be better achieved at Union level. 
Here the principle of subsidiarity serves to regulate the exercise of shared competences $^{45}$ between the Union and the Member States. The principle only applies in this case and therefore not to areas which fall within the exclusive competence of the European Union or those which exclusively fall within national competence. Nevertheless, this provision underlines the necessity to respect the competences of local and regional authorities within the European Union. According to this principle the Union does not take action - except in the areas which fall within its exclusive competence $^{46}$ - unless it is more effective than action taken at a national, regional or local level.

This principle is closely linked to the principles of proportionality and necessity, which require that any action by the Union should not go beyond what is necessary to achieve the objectives of the Treaty. ${ }^{47}$ The principle aims to ensure no intervention by the Union when an issue can be effectively regulated by the Member States at the central, regional or local level. So it aims to guarantee that decisions should be taken as closely as possible to the citizen; therefore also by local authorities. Also the European Parliament 'Emphasises that it is essential for scrutiny of the principle of subsidiarity to extend to the regional and local levels in the Member States'. ${ }^{48}$ With the entry into force of the Lisbon Treaty the Committee of the Regions ${ }^{49}$ obtained the right to bring an action before the Court of Justice of the European Union in two cases: first, on the ground of Article 263 TFEU to protect its own prerogatives and, secondly, on the basis of Article 8 Protocol $2,{ }^{50}$ on the ground of an infringement of the subsidiarity principle against legislative acts for the adoption of which the TFEU provides that it has to be consulted. The

45 The shared competences are enumerated in Article 4 Treaty on the Functioning of the European Union (TFEU).

46 See Article 3 TFEU.

47 Source: http://europa.eu/scadplus/glossary/subsidiarity_en.htm (last accessed 22 July 2014).

48 European Parliament resolution of 13 September 2012 on the 18th report on Better legislation - Application of the principles of subsidiarity and proportionality (2010).

49 The Committee of the Regions is an advisory body representing local and regional authorities in the European Union (Article 13 \$ 4 TEU and Articles 305, 306, 307 TFEU).

50 Protocol No. 2 on the application of the principles of subsidiarity and proportionality. Protocol attached to the Lisbon Treaty. http://eur-lex.europa.eu/ en/treaties/dat/12007L/htm/C2007306EN.01015001.htm (last accessed 22 July 2014). 
Committee of the Regions has therefore created an interactive network to monitor compliance with the subsidiarity principle. ${ }^{51}$

In practice, the real question concerning whether powers should be decentralized or not, or, in other words, when the principle of subsidiarity should be satisfied, is a complex one to answer. There are no general criteria which are applicable, let alone applicable everywhere in the same way. Much depends on the constitutional order in which the question arises. But even if the division of competences between the central and the decentralized authorities is regulated, the dividing lines may be blurred. Furthermore, the answer will not only depend on the national legal system or the national constitutional law, but on many other factors and circumstances - economic, political, socio-geographical, and so on than the strict juridical. Nevertheless, also in a case to case approach, the guideline for the assessment should be founded, in a state based on the rule of law, on the principle that decisions should be taken as closely as possible to the citizen and that that citizen may have an effective influence on decision making.

\section{LESSONS FROM IWRM AND CPRM}

\section{Common Pool Resource Management}

In 2009 Elinor Ostrom won the Nobel Prize for economics thanks to her outstanding research on the governance of common pools. Local water management was an important area of this research as part of its focus is on local-scale natural resources, like fisheries, water supplies, grazing land and forests. Just like local water management in the history of the Netherlands, a large role was reserved for agriculture. After decades of case study research Ostrom proposed her design principles for common pool research management, which we summarize below: ${ }^{52}$

\footnotetext{
51 On the monitoring see: https://portal.cor.europa.eu/subsidiarity/Pages/ default.aspx (last accessed 22 July 2014).

52 E. Ostrom, Governing the Commons: The Evolution of Institutions for Collective Action (Cambridge University Press, 2009); see also T. Dietz, E. Ostrom and P.C. Stern, 'The Struggle to Govern the Commons', (2003) 302 Science 1907-1912; and D. Armitage, 'Governance and the Commons in a Multi-level World', (2008) 2 International Journal of the Commons 7-32.
} 
- clearly defined boundaries;

- congruence between appropriation and provision rules and local conditions (restricted access);

- collective choice arrangements;

- monitoring;

- graduated sanctions;

- conflict-resolution mechanisms;

- minimal recognition of the right to organize;

- nested enterprises.

In later research the design principles were again investigated in order to determine whether they are also appropriate for the management of the global commons. They proved to be worthy at a global level as well. ${ }^{53}$

\section{Integrated Water Resource Management}

IWRM is described as 'a process which promotes the coordinated development and management of water, land and related resources in order to maximise the resultant economic and social welfare in an equitable manner without compromising the sustainability of vital ecosystems'. ${ }^{54}$ Although the concept of IWRM is rather vague, it has influenced the European Water Framework Directive and can also be recognized in Dutch water management. Huntjes identifies several principles that guide the IWRM:55

- apply IWRM at catchment level;

- integrate water and environmental management;

- follow a systems approach;

- full participation by all stakeholders, including workers and the community;

- attention to the social dimension;

- capacity building;

- availability of information and the capacity to use it so as to anticipate developments;

- full-cost pricing complemented by targeted subsidies;

53 Paul C. Stern, 'Design Principles for Global Commons: Natural Resources and Emerging Technologies', (2011) 5 International Journal of the Commons 213-232.

54 Global Water Partnership - Technical Advisory Committee, Integrated Water Resources Management, TAC Background Papers No. 4, Stockholm, 2000.

55 Huntjes (above, note 33), 36-37. 
- central government support through the creation and maintenance of an enabling environment;

- adaption of the best existing technologies and practices;

- reliable and sustained financing.

\section{AN INTEGRATED ASSESSMENT FRAMEWORK FOR WATER MANAGEMENT}

Improving water management involves combining principles from international and national law, IWRM and the CPRM and applying them to the proposed integrated approach of institutional, legal instrumental, economic and technical measures because only a combination of these four - guided by the above-mentioned principles - will lead to good water governance. One of the elements that we find in all the theories on good water management is the need for a multi-level approach with a strong role for water management by regional water authorities and/or local communities, and the need to relate water management and land use to each other. An emphasis on participation by all stakeholders is crucial. Also several forms of cost recovery can be found in all the discussed approaches, even as instruments to adapt ways of working due to lessons learned or circumstances that may change. Being financially selfsupporting and not dependent on general political struggles and vague institutions like 'the international community' or 'private companies or businesses' is of great importance in our view. It creates a community feeling with a shared responsibility. Unsustainable behaviour will return like a boomerang because the community will be directly harmed by this.

The river basin approach follows from Council Decision 95/308/EC of 24 July 1995 on the conclusion, on behalf of the Community, of the Convention on the protection and use of trans-boundary watercourses and international lakes (Helsinki Convention) and the EU Water Framework Directive, but is also relevant in water management in, for example, Australia and the United States. The main element is that water management must be based on hydrological borders, but the appropriate scale may differ from time to time and from place to place, and it also depends on the water issues that are at stake (flooding, irrigation, waste water treatment). Examples of institutional scale differences are the Congo River basin, which is almost the same as the state borders, and the Danube River basin, which is shared by many states. But we can also use hydrological borders for very local and regional water management, as witnessed by the history of water management in the Netherlands. 
The Netherlands, with its long-lasting tradition of local and regional water management, provides a good example and lessons learned from many mistakes to achieve resilient, sustainable local water management, although the Dutch system is far from perfect and can certainly be improved. The Dutch system will be elaborated in the following sections of this chapter.

\section{APPLYING THE ASSESSMENT FRAMEWORK TO THE INSTITUTIONAL MODEL OF REGIONAL WATER MANAGEMENT IN THE NETHERLANDS}

Before delving into the Dutch institutional arrangement for regional water management, we will provide some facts and figures. ${ }^{56}$ The Netherlands is a delta in North-West Europe with a surface of 41,526 $\mathrm{km}^{2}$, of which 18 per cent is surface water. It has 16,515,057 inhabitants, which means that the population density is very high: 397.7 inhabitants per square kilometre. Around two-thirds of the population live in an area with a serious flood risk and almost 60 per cent of the country is threatened by floods (from rivers or the North Sea). The country has 3291 kilometres of dikes and dams, 268 kilometres of dunes, 808 artificial water works to protect against flooding, and there are over 3000 polders that must be drained. The quality of drinking water is good, but the chemical and ecological statuses of waters are insufficient. The Netherlands forms part of four transboundary river basins: Rhine, Meuse, Ems and Scheldt. It will be apparent that the Netherlands is a very small, intensely populated country where good water management is crucial for survival. Each new problem is immediately urgent and requires adaptive and strong solutions as well as transboundary cooperation within the whole river basin.

\section{Water Problems}

Looking at the water problems in the Netherlands we see that they are the same as in many other countries. They can only be solved by an

56 H.J.M. Havekes and H. van Rijswick, European and Dutch Water Law (Europa Law Publishing, 2012) and S. Reinhard and H. Folmer (eds.), Water Policy in the Netherlands: Integrated Management in a Densely Populated Delta (Issues in water resource policy, RFF Press, 2009). 
integrated approach with land-use planning, environmental law, agriculture, nature conservation, economic development and, above all, transparency concerning the obligations of government and citizens.

The risk of flooding is a problem which has long existed and the main solutions in the past have been the building of dikes and the draining of redundant water into the sea. Local and regional solutions are nowadays found in a further integration of land-use planning and water management, mostly by water storage which, on the one hand, avoids flooding and, on the other, saves water for times of water scarcity. However, in such a small country room for water is difficult to find and dams are not an option (the country is largely flat). Conflicts over scarce land are very common and are often solved by the fact there is an awareness of the need for protection against flooding, although opinions on the best way to deal with flooding may differ.

Due to intensive land use, agriculture and industrial development, water quality was extremely poor during the 1970s. The fact that the Netherlands is located at the end of four international river basins has increased water quality problems. The introduction of a legal system that combined licences with a system of levies per amount of pollution improved water quality enormously and can be seen as the greatest success in Dutch environmental law. The fact that it was the local water authorities which received the taxes and the fact that they were only allowed to invest this tax revenue in the improvement of water quality, for example by building waste water treatment plants and cleaning polluted river bed soil and watercourses, was the most significant factor of the water quality legislation. Because the levies were fairly high it was more profitable for industry to invest in waste water treatment than in discharging polluted water. This was combined with the cooperation of all local water authorities in investing in and sharing technical knowledge.

The Netherlands has been confronted with an increasing lack of water - although it is not as serious as in Southern Europe, Africa or Australia - and we still have to learn how to deal with this. The challenge will be to find mechanisms for a fair distribution, based on a sustainable use and application and solidarity. As an example we mention the European and Dutch approach to dealing with water scarcity with a European obligation to create a balance between abstractions and natural refills and the Dutch ranking system based on the protection of the most vulnerable interests. In the European approach there is a Communication by the European Commission on water scarcity and droughts, which emphasizes the pricing of water use; an efficient allocation of water; drought risk management; the integration of water interests in other 
policy fields; efficient water technology; stimulating the saving of water; improving knowledge; and, only as a last resort, the building of water infrastructure works. In the Dutch approach the focus lies on the realization of a balance between supply and demand, by way of planning; a legal ranking of water use in times of drought/water scarcity (a water hierarchy); licences based on a first come, first served approach; temporary prohibitions of irrigation; water agreements between water authorities; emergency plans; and a legal obligation to take water interests into account in land-use planning. We can conclude that in the Netherlands enforceable legal instruments to deal with water scarcity are most important. In the Netherlands there is no system of tradable water rights or a water market.

High pressure, an awareness gap and climate change are new problems to be tackled. Due to the dense population there are many users, such as individuals, agriculture, drinking water companies, energy supply, industry, tourism, shipping, fishing, and so on. Since water scarcity is a rather new phenomenon, people think that they have unlimited right to (almost) free water (services) and have an almost blind trust in the government organizing protection against flooding and supplying clean, fresh water as well as drinking water. However, climate change will lead to more periods of water shortage and more flooding, and therefore there is a strong need to rethink the existing governance and distribution mechanisms..$^{57}$

\section{Institutional Organization of Water Management in the Netherlands}

Flooding is a historical problem for the Netherlands and there have been hundreds of cases of serious flooding over the last few centuries. The regional solution to solve these flooding problems has been working fairly well, but many lessons have also been learned in a rather dramatic way, with many lives lost. Important problems were the insufficient

57 C. Termeer et al., 'The Regional Governance of Climate Adaptation: A Framework for Developing Legitimate, Effective and Resilient Governance Arrangements', (2011) 1 Climate Law 1-21; P.P.J. Driessen and H.F.M.W. van Rijswick, 'Normative Aspects of Climate Adaptation Policy', (2011) 2 Climate Law 1-23; F. Sultana and A. Loftus (eds.), The Right to Water: Politics, Governance and Social Struggles (Earthscan, 2011); E. Hey and H. van Rijswick, 'Transnational Water Management', in Oswald Jansen and Bettina Schöndorf-Haubold (eds.), The European Composite Administration (Intersentia, 2011), 227-249. 
attention being given to risks (a weak role for the precautionary principle), a lack of money to make the necessary investments, poor attention to vulnerable interests and stakeholders, a lack of solidarity, too much attention to the particular interests of those who had power and, of course, nature itself as an unpredictable and sometimes devastating force. Another lesson learned was that close interaction with the national and international level with whom river basins are shared is also necessary. Looking at the long tradition of regional and local water management and the fact that the Netherlands is one of the safest deltas in the world, even though it lies, for a great part, below sea level, it can be concluded that the legal institutional framework of water boards has proved to be an adaptive organizational form of regional water management. Crucial for understanding Dutch water management is the fact that water is a public good, just like, for example, in South Africa and Canada. Also, in the European Union water has a special status, being a heritage that must be dealt with and defended as such (preamble to the Water Framework Directive).

\section{Shared competences}

Regional management started around the year 1000 on a very small scale - involving only a few square kilometres - as a form of cooperation between those who had an interest in good water management but were not able to realize this on their own. These thousands of cooperative arrangements - in the Netherlands now called 'waterschappen' (regional water authorities or water boards) - developed over time into regional public water authorities with their own powers for regulation, enforcement, conflict resolution and the ability to raise taxes. Water management in the Netherlands is still a shared responsibility between two levels of water authorities with management competences based on the Water Act. These are the Minister of Infrastructure and the Environment (competent for larger water systems including the marine environment) and the 24 Water Boards, responsible for regional water systems, including groundwater and waste water treatment. ${ }^{58}$ Besides the central and regional level, provinces have a role in strategic regional planning, the coordination and supervision of municipalities and water boards, and they are the competent authorities for granting licences for large-scale water abstractions (> 150,000 litres a year). Municipalities also have a duty of care for urban water management and land-use planning.

58 Regulated in the Water Act and the Water Boards Act. 


\section{Formal legal relation between stake, say and pay}

In Dutch regional water management, from the very beginning there was a relationship between 'stake, say and pay'. This means that payments were related to the stake or interest that one had in the work of the water board. There was also a relation between the say (participation in the representative board) related to the stake one had. Payments were originally made in natura, but were later replaced by a tax system. It was crucial that all the taxes that were paid were only allowed to be invested in the same regional or local water system or basin, so payments were profitable for all stakeholders.

We can see two forms of representation of those who have an interest - a stake - in local or regional water management. One is representation by designation, which is the case for the interests of agriculture, nature conservation organizations and industry/commerce. The other is representation by direct elections. Representation is important because of the slogan of 'no taxation without representation'. Representatives were in the past mainly chosen based on their expertise and not because they were members of a political party. This non-political system provided an opportunity for long-term investments and maintenance that enables a more sustainable approach, because one can look 50 or 100 years ahead instead of only to the next elections. It must be said that in recent years several amendments have been made to this system, which have led to a less stringent relationship between stay, say and pay. Because of the transition from a mainly agricultural to an urbanized society, the awareness of the need for good water governance had diminished. Although people who live in urban regions have the same obligation to pay taxes to the water boards, they are not so directly dependent on the work of the water authorities. This would be different if the Netherlands had problems with a good drinking-water supply, but that is not the case. Another recent change is the possibility for political parties to join the elections, but although it was expected that this would lead to a change in water management, the differences seem to be minor. This is explained by the fact that water boards are functional authorities with only one task: good water management. That does not leave much room for political choices: there are no liberal or socialist dikes.

\section{Financial autonomy}

The financial arrangements are a crucial element in the institutional organization of Dutch regional water management. In the Dutch system there is also a relation between one's interest in good water management and the financial contribution one has to make, based on the amount of land one owns or the value of one's real estate. It is a closed and 
self-supporting system: those whose interests are at stake make the decisions and pay for the water management measures. This relationship between say, stake and pay creates a shared long-term responsibility and encourages sustainable behaviour, although, of course, not in a perfect way. It must be stated that this closed system does not exist at the Dutch state level: investments in water management by the Ministry are paid for by general tax revenue and they are hardly related to those who profit from water services. We can see the same approach in EU water law using the cost recovery principle of water services (which includes the polluter pays principle) but it is not that effective since it does not require that all the gathered revenue has to be invested in the improvement of the status of river basins.

Taking a closer look at the several taxes for water management, we can note the following water services for which people have to pay:

- a tax on the use of groundwater, but no tax or charge for the use of surface water;

- paying for drinking-water services (Euro 1.50 for 1000 litres of clean healthy water);

- specific charges to pay the water boards for

- water system management, which is mainly based on the solidarity principle

- the treatment of waste water, which is based on the profit principle;

- general taxes to pay the general government, which are not allocated for water management or water services.

\section{Assessment of the Dutch Approach in Central and Regional Water Management}

When we look at the Dutch institutional legal framework for water management, we can see that at the regional level most requirements, as they follow from the analytical assessment framework (see sections 3-6), are being met. See Table 12.1. Comparing this with the institutional legal organization at the state level, we can conclude that the concept of decentralization, and especially the concept of functional decentralization, in which there are specific institutions for water management (but which are still related to other policy fields), best meet the requirements, as developed from international law (general principles), IWRM and CPRM. 
Table 12.1 Assessment of Dutch water management

\begin{tabular}{|c|c|c|c|c|c|}
\hline & $\begin{array}{l}\text { General } \\
\text { principles }\end{array}$ & IWRM & CPRM & $\begin{array}{l}\text { Dutch water } \\
\text { management } \\
\text { at the central } \\
\text { level }\end{array}$ & $\begin{array}{l}\text { The Dutch } \\
\text { decentralized } \\
\text { water } \\
\text { authorities }\end{array}$ \\
\hline Institutional & Subsidiarity & $\begin{array}{l}\text { IWRM } \\
\text { applied at } \\
\text { catchment } \\
\text { level }\end{array}$ & $\begin{array}{l}\text { Clearly } \\
\text { defined } \\
\text { boundaries }\end{array}$ & & $\begin{array}{l}\text { Regional water } \\
\text { authorities are } \\
\text { the competent } \\
\text { authority for } \\
\text { water } \\
\text { management, } \\
\text { unless matters } \\
\text { can be better } \\
\text { arranged at the } \\
\text { central level }\end{array}$ \\
\hline Institutional & Decentralization & $\begin{array}{l}\text { Central } \\
\text { government } \\
\text { support } \\
\text { through the } \\
\text { creation and } \\
\text { maintenance } \\
\text { of an } \\
\text { enabling } \\
\text { environment }\end{array}$ & $\begin{array}{l}\text { Nested } \\
\text { enterprises }\end{array}$ & & $\begin{array}{l}\text { The } \\
\text { decentralization } \\
\text { principle is } \\
\text { explicitly laid } \\
\text { down in the Act } \\
\text { on water boards }\end{array}$ \\
\hline Institutional & $\begin{array}{l}\text { Protection of } \\
\text { property } \\
\text { rights }\end{array}$ & & $\begin{array}{l}\text { Conflict- } \\
\text { resolution } \\
\text { mechanisms }\end{array}$ & $\begin{array}{l}\text { General } \\
\text { representation } \\
\text { in Parliament, } \\
\text { where } \\
\text { interests } \\
\text { concerning } \\
\text { water } \\
\text { management } \\
\text { have to } \\
\text { compete with } \\
\text { many other } \\
\text { interests }\end{array}$ & $\begin{array}{l}\text { All inhabitants } \\
\text { with a stake } \\
\text { therein are part } \\
\text { of the } \\
\text { representation } \\
\text { model and pay } \\
\text { their part of the } \\
\text { taxes. Because } \\
\text { of the } \\
\text { democratic } \\
\text { organization, } \\
\text { most conflicts } \\
\text { are solved } \\
\text { within the } \\
\text { community. In } \\
\text { the end there is } \\
\text { the possibility to } \\
\text { resort to the } \\
\text { courts }\end{array}$ \\
\hline $\begin{array}{l}\text { Institutional } \\
\text { and legal } \\
\text { instrument }\end{array}$ & Proportionality & & $\begin{array}{l}\text { Graduated } \\
\text { sanctions }\end{array}$ & $\begin{array}{l}\text { The central } \\
\text { water } \\
\text { authority has } \\
\text { the power to } \\
\text { sanction but } \\
\text { is restricted } \\
\text { by the rule of } \\
\text { law. A }\end{array}$ & $\begin{array}{l}\text { Water boards } \\
\text { have the power } \\
\text { to sanction but } \\
\text { are restricted by } \\
\text { the rule of law. A } \\
\text { differentiated } \\
\text { system of } \\
\text { sanctions exists }\end{array}$ \\
\hline
\end{tabular}




\begin{tabular}{|c|c|c|c|c|c|}
\hline & $\begin{array}{l}\text { General } \\
\text { principles }\end{array}$ & IWRM & CPRM & $\begin{array}{l}\text { Dutch water } \\
\text { management } \\
\text { at the central } \\
\text { level }\end{array}$ & $\begin{array}{l}\text { The Dutch } \\
\text { decentralized } \\
\text { water } \\
\text { authorities }\end{array}$ \\
\hline & & & & $\begin{array}{l}\text { differentiated } \\
\text { system of } \\
\text { sanctions } \\
\text { exists }\end{array}$ & \\
\hline Institutional & $\begin{array}{l}\text { Equity: } \\
\text { procedural, } \\
\text { substantial } \\
\text { fairness }\end{array}$ & & $\begin{array}{l}\text { Collective } \\
\text { choice } \\
\text { arrangements }\end{array}$ & $\begin{array}{l}\text { General } \\
\text { representation } \\
\text { in Parliament, } \\
\text { where } \\
\text { interests } \\
\text { concerning } \\
\text { water } \\
\text { management } \\
\text { have to } \\
\text { compete with } \\
\text { many other } \\
\text { interests }\end{array}$ & $\begin{array}{l}\text { Stakeholder } \\
\text { participation is } \\
\text { the formal basis } \\
\text { for membership } \\
\text { of the } \\
\text { representative } \\
\text { board. Several } \\
\text { kinds of } \\
\text { stakeholders } \\
\text { have a formal } \\
\text { representation }\end{array}$ \\
\hline $\begin{array}{l}\text { Institutional } \\
\text { and legal } \\
\text { instrument }\end{array}$ & & $\begin{array}{l}\text { Integrate } \\
\text { water and } \\
\text { environmental } \\
\text { management }\end{array}$ & & $\begin{array}{l}\text { Although } \\
\text { there are } \\
\text { different } \\
\text { competent } \\
\text { authorities for } \\
\text { environmental, } \\
\text { water and } \\
\text { spatial } \\
\text { planning, } \\
\text { water } \\
\text { management } \\
\text { is coordinated } \\
\text { at most levels } \\
\text { with spatial } \\
\text { planning, } \\
\text { land use and } \\
\text { environmental } \\
\text { protection by } \\
\text { way of } \\
\text { planning, } \\
\text { agreements, } \\
\text { coordination } \\
\text { in } \\
\text { environmental } \\
\text { and water } \\
\text { licences and a } \\
\text { water test for } \\
\text { water and } \\
\text { spatial } \\
\text { planning }\end{array}$ & $\begin{array}{l}\text { Although there } \\
\text { are different } \\
\text { competent } \\
\text { authorities for } \\
\text { environmental, } \\
\text { water and } \\
\text { spatial planning, } \\
\text { water } \\
\text { management is } \\
\text { coordinated at } \\
\text { most levels with } \\
\text { spatial planning, } \\
\text { land use and } \\
\text { environmental } \\
\text { protection by } \\
\text { way of planning, } \\
\text { agreements, } \\
\text { coordination in } \\
\text { environmental } \\
\text { and water } \\
\text { licences and a } \\
\text { water test for } \\
\text { water and } \\
\text { spatial planning }\end{array}$ \\
\hline Institutional & $\begin{array}{l}\text { Good } \\
\text { neighbourliness }\end{array}$ & $\begin{array}{l}\text { Full } \\
\text { participation }\end{array}$ & $\begin{array}{l}\text { Minimal } \\
\text { recognition }\end{array}$ & $\begin{array}{l}\text { See above on } \\
\text { general }\end{array}$ & $\begin{array}{l}\text { Management } \\
\text { should be }\end{array}$ \\
\hline
\end{tabular}




\begin{tabular}{|c|c|c|c|c|c|}
\hline & $\begin{array}{l}\text { General } \\
\text { principles }\end{array}$ & IWRM & CPRM & $\begin{array}{l}\text { Dutch water } \\
\text { management } \\
\text { at the central } \\
\text { level }\end{array}$ & $\begin{array}{l}\text { The Dutch } \\
\text { decentralized } \\
\text { water } \\
\text { authorities }\end{array}$ \\
\hline & & $\begin{array}{l}\text { by all } \\
\text { stakeholders }\end{array}$ & $\begin{array}{l}\text { of the right } \\
\text { to organize }\end{array}$ & $\begin{array}{l}\text { elections. } \\
\text { When } \\
\text { looking at } \\
\text { transboundary } \\
\text { river basins it } \\
\text { is the central } \\
\text { level that } \\
\text { takes care of } \\
\text { the principle } \\
\text { of good } \\
\text { neighbourliness }\end{array}$ & $\begin{array}{l}\text { coordinated } \\
\text { with } \\
\text { neighbouring } \\
\text { water } \\
\text { authorities and } \\
\text { sub-river basins }\end{array}$ \\
\hline $\begin{array}{l}\text { Institutional } \\
\text { and } \\
\text { economic }\end{array}$ & $\begin{array}{l}\text { The user and } \\
\text { polluter pays } \\
\text { principle/ } \\
\text { cost recovery } \\
\text { for water } \\
\text { services }\end{array}$ & $\begin{array}{l}\text { Reliable and } \\
\text { sustained } \\
\text { financing }\end{array}$ & & $\begin{array}{l}\text { No full } \\
\text { recovery of } \\
\text { costs for } \\
\text { water } \\
\text { services. No } \\
\text { reliable and } \\
\text { sustained } \\
\text { financing } \\
\text { because of } \\
\text { several } \\
\text { competing } \\
\text { interests at } \\
\text { the central } \\
\text { level }\end{array}$ & $\begin{array}{l}\text { All stakeholders } \\
\text { have to pay } \\
\text { taxes, } \\
\text { depending (not } \\
\text { fully) on their } \\
\text { protected } \\
\text { interests. Tax } \\
\text { incomes may } \\
\text { only be used for } \\
\text { water } \\
\text { management } \\
\text { within the } \\
\text { sub-river basin } \\
\text { of the competent } \\
\text { water authority }\end{array}$ \\
\hline $\begin{array}{l}\text { Institutional } \\
\text { and } \\
\text { economic }\end{array}$ & $\begin{array}{l}\text { The user and } \\
\text { polluter pays } \\
\text { principle/ } \\
\text { cost recovery } \\
\text { for water } \\
\text { services }\end{array}$ & $\begin{array}{l}\text { Full-cost } \\
\text { pricing } \\
\text { complemented } \\
\text { by targeted } \\
\text { subsidies }\end{array}$ & & $\begin{array}{l}\text { No full } \\
\text { recovery of } \\
\text { costs for } \\
\text { water } \\
\text { services }\end{array}$ & $\begin{array}{l}\text { All stakeholders } \\
\text { have to pay } \\
\text { taxes, } \\
\text { depending (not } \\
\text { fully) on their } \\
\text { protected } \\
\text { interests. Tax } \\
\text { incomes may } \\
\text { only be used for } \\
\text { water } \\
\text { management } \\
\text { within the } \\
\text { sub-river basin } \\
\text { of the competent } \\
\text { water authority }\end{array}$ \\
\hline Institutional & $\begin{array}{l}\text { Solidarity: } \\
\text { distributive } \\
\text { fairness }\end{array}$ & $\begin{array}{l}\text { Attention to } \\
\text { the social } \\
\text { dimension }\end{array}$ & & $\begin{array}{l}\text { The system at } \\
\text { state level is } \\
\text { mainly based } \\
\text { on solidarity, } \\
\text { but depends } \\
\text { in practice on } \\
\text { strong }\end{array}$ & $\begin{array}{l}\text { All inhabitants } \\
\text { and } \\
\text { stakeholders } \\
\text { must be } \\
\text { represented. The } \\
\text { tax system } \\
\text { leaves room for }\end{array}$ \\
\hline
\end{tabular}




\begin{tabular}{|c|c|c|c|c|c|}
\hline & $\begin{array}{l}\text { General } \\
\text { principles }\end{array}$ & IWRM & CPRM & $\begin{array}{l}\text { Dutch water } \\
\text { management } \\
\text { at the central } \\
\text { level }\end{array}$ & $\begin{array}{l}\text { The Dutch } \\
\text { decentralized } \\
\text { water } \\
\text { authorities }\end{array}$ \\
\hline & & & & $\begin{array}{l}\text { lobbying by } \\
\text { certain } \\
\text { sectors } \\
\text { (agriculture, } \\
\text { industry) }\end{array}$ & $\begin{array}{l}\text { a solidarity } \\
\text { approach }\end{array}$ \\
\hline Institutional & $\begin{array}{l}\text { Sustainability } \\
\text { and non-shift } \\
\text { principle }\end{array}$ & $\begin{array}{l}\text { Adaptation } \\
\text { of the best } \\
\text { existing } \\
\text { technologies } \\
\text { and } \\
\text { practices }\end{array}$ & & $\begin{array}{l}\text { By holding } \\
\text { elections } \\
\text { every four } \\
\text { years with } \\
\text { their own } \\
\text { actual topics } \\
\text { it is difficult } \\
\text { to obtain } \\
\text { votes for } \\
\text { long-term } \\
\text { investments }\end{array}$ & $\begin{array}{l}\text { The relation } \\
\text { between stake, } \\
\text { say and pay } \\
\text { improves } \\
\text { sustainable } \\
\text { behaviour. The } \\
\text { self-financing } \\
\text { system can } \\
\text { prevent the } \\
\text { shifting of } \\
\text { problems onto } \\
\text { others }\end{array}$ \\
\hline Institutional & $\begin{array}{l}\text { Precautionary } \\
\text { principle }\end{array}$ & $\begin{array}{l}\text { Availability } \\
\text { of } \\
\text { information } \\
\text { and the } \\
\text { capacity to } \\
\text { use it to } \\
\text { anticipate } \\
\text { developments }\end{array}$ & Monitoring & $\begin{array}{l}\text { Due to the } \\
\text { strong focus } \\
\text { on economic } \\
\text { development, } \\
\text { attention to } \\
\text { ecology and } \\
\text { long-term } \\
\text { investment in } \\
\text { water } \\
\text { management } \\
\text { is small }\end{array}$ & $\begin{array}{l}\text { The system was } \\
\text { originally not } \\
\text { very political } \\
\text { and based on } \\
\text { long-term } \\
\text { protection also } \\
\text { for future } \\
\text { generations }\end{array}$ \\
\hline $\begin{array}{l}\text { Institutional, } \\
\text { legal } \\
\text { instrument } \\
\text { and } \\
\text { technical } \\
\text { element }\end{array}$ & & $\begin{array}{l}\text { Capacity } \\
\text { building }\end{array}$ & & $\begin{array}{l}\text { The } \\
\text { 'Rijkswaterstaat' } \\
\text { Agency has } \\
\text { the same } \\
\text { power of } \\
\text { capacity } \\
\text { building as } \\
\text { the regional } \\
\text { water boards }\end{array}$ & $\begin{array}{l}\text { Due to its long } \\
\text { tradition, } \\
\text { capacity } \\
\text { building is one } \\
\text { of the strong } \\
\text { elements }\end{array}$ \\
\hline
\end{tabular}

\section{CONCLUSIONS}

Our purpose in this chapter is not to promote the Dutch regional model for water management as being 'the best', but to show which elements have been working well in the Netherlands using the developed assessment framework above. Based on various research projects that have 
been carried out by many scholars from different disciplines (international law, European and national water law, social sciences and economics), and which show that the Dutch delta is a safe place to live, where water quality is moderate to rather good, where ecosystems are protected in a reasonable way, and where there is clean and safe water for all, we consider that the following elements are important for achieving resilient and sustainable water management:

- water as a public good;

- decentralization and subsidiarity by water management at the local or regional level;

- water management based on hydrological borders;

- financially self-supporting;

- strong public participation in decision making by representative democracy and public participation in planning and decision making;

- followed by easy and cheap access to administrative courts, both for individuals as well as non-governmental organizations;

- and a relation between stake, say and pay.

Of course, attention to local and national diversity is also necessary to achieve fair, equitable and sustainable water management. We conclude that sustainable water management needs an integrated and combined approach, combining governance (institutional, legal, economic) and technical arrangements. This conclusion is based on basic concepts of good water governance, in which we can find the same elements in several theories.

Thinking of and using leading principles may help in a period of change towards a sustainable and fair use of water resources, especially when societies have to deal with the rather unpredictable but often severe impacts of climate change. For good water management both substantive and procedural legal arrangements are necessary and a good legal institutional framework can support the path towards sustainable water management. River basin management and a local/regional approach with strong stakeholder participation and a relation between 'stake-paysay' has proven to work well, at least in the Netherlands. The scale of a water management unit (a sub-river basin) depends on the public or water task that is at stake and more than one scale can be managed at the same point in time. Nowadays the shift towards more centralization and the enlargement of management units (sub-river basins) may be necessary because of expensive waste water treatment installations and the sharing 
of costs for flood protection works, but may cause problems in the future from the perspective of the above-described good water governance approach.

The Dutch approach does not fulfil all these requirements for good water governance and a sustainable water resource management, but is still inspiring due to its long tradition and success..$^{59}$ As stated above, the Dutch delta is a safe place to live, there is access to clean water for all, and water quality has improved enormously in the last few decades. Water quality has improved most of all compared with other environmental components and far more than the quality of soil, air and noise. Waste water treatment is of a high level.

An important reason for this is the fact that the institutional arrangement provides for sufficient resources to tackle flood risks, pollution and waste water treatment, and that measures are based on commitment at the local level, combined with regulations at the national level. What should be improved at the central level is a fair balance between what is at stake and payment by all water (service) users, especially as agriculture has a privileged position in the Netherlands. Furthermore, it should be noted that most political parties in the Netherlands want to abolish the water boards. The reasons for this are that too many governmental layers are now involved in water, land use and environmental matters, and the fact that not many people (between 20-30 per cent) use their right to vote when electing the water boards. However, no appropriate alternative that provides for decentralization, the direct involvement of the public and financial autonomy, and which is based on river basin districts, has so far been suggested. We conclude that a local/regional model, which is based on sub-river basins and is financially self-supporting with strong public participation and easy and cheap access to the courts for individuals and non-governmental organizations, and a direct relation between say, stake and pay, is the most profitable for fair, equitable and sustainable water management and enhances adaptive and resilient water management.

59 OECD, Studies on Water: 'Water Governance in the Netherlands: Fit for the Future?' (OECD, 2014). 